\title{
Bacterial Diversity and Community in Response to Long-Term Nitrogen Fertilization Gradient in Citrus Orchard Soils
}

\author{
Yu Wan ${ }^{1,2}$, Wenjie $\mathrm{Li}^{1,2, *}$, Jie Wang ${ }^{3}$ and Xiaojun $\mathrm{Shi}^{3}(\mathbb{D}$ \\ 1 National Inland Waterway Regulation Engineering Research Center, Chongqing Jiaotong University, \\ Chongqing 400074, China; wanyu_hhxy@cqjtu.edu.cn \\ 2 School of River and Ocean Engineering, Chongqing Jiaotong University, Chongqing 400074, China \\ 3 College of Resources and Environment, Southwest University, Chongqing 400074, China; \\ mutouyu@swu.edu.cn (J.W.); shixj@swu.edu.cn (X.S.) \\ * Correspondence:990020110723@cqjtu.edu.cn
}

check for updates

Citation: Wan, Y.; Li, W.; Wang, J.; Shi, X. Bacterial Diversity and Community in Response to Long-Term Nitrogen Fertilization Gradient in Citrus Orchard Soils. Diversity 2021, 13, 282. https:/ / doi.org/10.3390/d13070282

\section{Academic Editors:}

David Johnston-Monje and

Alejandro Caro-Quintero

Received: 1 May 2021

Accepted: 19 June 2021

Published: 23 June 2021

Publisher's Note: MDPI stays neutral with regard to jurisdictional claims in published maps and institutional affiliations.

Copyright: (c) 2021 by the authors. Licensee MDPI, Basel, Switzerland. This article is an open access article distributed under the terms and conditions of the Creative Commons Attribution (CC BY) license (https:/ / creativecommons.org/licenses/by/ $4.0 /)$.

\begin{abstract}
Citrus orchards receive increasing amounts of nitrogen fertilizer for the purpose of optimal yields and good quality of citrus fruits. Although the effects of increased nitrogen fertilizer on citrus fruit trees have been reasonably well studied, few comparable studies have examined impacts on soil bacterial communities and diversity, even though they play critical roles in orchard ecosystem functioning. In our study, Illumina MiSeq sequencing was used to investigate bacterial community structure and diversity under 5-years long-term nitrogen fertilization gradients (N0, N1, N2, N3, $\mathrm{N} 4$, and N5) in citrus orchard soils. The sequencing result showed that nitrogen fertilizer addition increased bacterial diversity along the $\mathrm{N} 0$ to $\mathrm{N} 3$ gradient but decreased bacterial diversity along the N3 to N5 gradient. The increase in the nitrogen fertilizer rate altered bacterial community composition by increasing the relative abundance of Delta-proteobacteria, Nitrospirae, SBR1093, and Latescibacteria and decreasing the relative abundance of Alpha-proteobacteria. Finally, regression analysis revealed that bacterial diversity and the relative abundance of Nitrosomonadales, Rhodobiaceae, Gemmatimonas, and Variibacter exhibited a significant positive correlation with citrus yield. The study revealed that a reasonable nitrogen fertilizer rate applied to citrus orchards could improve bacterial community structure and diversity and increase citrus yield.
\end{abstract}

Keywords: bacterial diversity; bacterial community structure; nitrogen fertilization gradient; citrus yield; orchard soil

\section{Introduction}

Soil microorganisms are important components of ecosystems, and they are involved in fundamental activities that ensure the stability and productivity of both agricultural and natural ecosystems [1]. Microorganisms in the soil ecosystem are responsible for many fundamental ecological processes, such as the biogeochemical cycling of chemical elements and the decomposition of plant and animal residues [2]. These considerations demonstrate the importance of studying the structural and functional properties of microbial communities in the soil ecosystem and the ways in which various factors influence bacterial diversity [1].

The soil of the orchard ecosystem harbors an abundance of microbial communities, and soil bacteria are closely associated with soil nutrient cycling and plant disease prevention [3]. The bacterial community species and their influencing factors in orchard soil have been well studied so far. For example, Zhou et al. (2011) found that long-term application of fungicides had adverse effects on microbial biomass and bacterial community diversity in citrus orchard soil [4]. Other research in Hangzhou found soil microbial community diversity index increased with the liming rate in the tea orchard soil [5]. These investigations contribute to a broad understanding of the orchard microbial community's structural characteristics. 
The application of chemical fertilizers could maintain or increase the yield of crops and fruit trees to a certain extent and cause changes in the physicochemical and biological properties of the soil. It has been thought that these changes are closely related to soil quality and productivity [6]. Long-term influence of chemical fertilizer on soil microbial biomass and microbial diversity was documented by several researchers but no consensus has been reached so far. The long-term effects of fertilizer application on soil bacterial community structure and biodiversity have been confirmed by many researchers, but there is no consensus at present. For instance, several studies documented that chemical fertilizer increased microbial biomass and microbial diversity [6,7] but was contradicted by Sarathchandra et al. (2001) where the authors reported that application of nitrogen fertilizer did not significantly affect soil microbial community structure [8,9]. Therefore, based on previous studies, our study hypothesized that rational fertilizer application could increase microbial diversity.

Citrus trees, as one of the most valuable fruit trees in the world, have the highest yield (45.85 million tons; 2019) and planting area (2.62 million hectares; 2019) in China [10]. Based on the China statistical yearbook (2016) [11], farmer practice of nitrogen fertilizer in the major citrus-producing province of China was about $300 \sim 800 \mathrm{~kg} / \mathrm{ha}$. However, excessive nitrogen fertilizer application will lead to a decrease in nutrient absorption and fertilizer utilization, so it may not significantly improve the yield of citrus. Soil microbial community in citrus orchards play an important role in releasing soil nutrients and preventing plant diseases [3] and play an important role in promoting citrus growth and health [12]. In recent years, there have been many studies about the effects of irrigation regime, tillage method, citrus tree tissues, and citrus disease on microbial community [13-15]. Nevertheless, the relationship between nitrogen application rate, citrus yield, and microbial community should also be studied. In our research, the high-throughput sequencing method was used to analyze the bacterial community structure characteristics in citrus orchard soil under long-term nitrogen fertilizer application. The specific objectives of this study were (1) to investigate the effects of long-term nitrogen fertilization gradient on soil nutrient levels and citrus yields, and (2) to determine the response of bacterial community and diversity to long-term nitrogen fertilization gradient.

\section{Materials and Methods}

\subsection{Experimental Design}

The field experiment is located in Wanzhou District, Chongqing Municipality, China $\left(30^{\circ} 40^{\prime} 1^{\prime \prime} \mathrm{N}, 108^{\circ} 15^{\prime} 5^{\prime \prime} \mathrm{E}\right)$. This region has a subtropical humid monsoon climate, with an average annual temperature of $18.2^{\circ} \mathrm{C}$ and mean annual precipitation of $1150 \mathrm{~mm}$. The area is dominated by purple soil, classified as a Eutric Regosol, and developed from fast physical weathering purple mudstone of the Trias-Cretaceous system.

The long-term nitrogen fertilizer experiment area was $1200 \mathrm{~m}^{2}$, and the planting density was 800 tree ha ${ }^{-1}$ ( $2.5 \mathrm{~m}$ between citrus trees and $5 \mathrm{~m}$ between each row). The citrus orchards were constructed in 2006, and the variety of citrus was Tarocco blood orange that grafted on Poncirus trifoliata (L.). Beginning in March 2013, the experiment was designed with six nitrogen fertilization gradient treatments, i.e., $\mathrm{CH}_{4} \mathrm{~N}_{2} \mathrm{O}$, and each treatment consisted of 16 citrus trees. Six nitrogen fertilization gradient treatments (N0, $\mathrm{N} 1, \mathrm{~N} 2, \mathrm{~N} 3, \mathrm{~N} 4$, and N5) used were as follows: $0,1,1.5,2,2.5$, and $3 \mathrm{~kg} \cdot$ urea tree $^{-1} \cdot \mathrm{year}^{-1}$ $\left(0,0.46,0.69,0.92,1.15\right.$, and $1.38 \mathrm{~kg} \cdot \mathrm{N}$ tree $\left.{ }^{-1} \cdot \mathrm{year}^{-1}\right)$. Six treatments also received phosphatic fertilizer as $\mathrm{Ca}\left(\mathrm{H}_{2} \mathrm{PO}_{4}\right)_{2} \cdot \mathrm{H}_{2} \mathrm{O}\left(2.5 \mathrm{~kg}\right.$. tree ${ }^{-1} \cdot$ year $\left.^{-1}\right)$ and potash fertilizer as $\mathrm{K}_{2} \mathrm{SO}_{4}$ $\left(1.5 \mathrm{~kg} \cdot \mathrm{tree}^{-1} \cdot \mathrm{year}^{-1}\right)$. In March, July, and October, nitrogen fertilizer was applied at rates of 50,50, and 0\%; phosphatic fertilizer applied at rates of 20, 20, and 60\%; and potash fertilizer applied at rates of 25,50 , and $25 \%$, respectively.

\subsection{Soil Sampling}

Soil sampling for our study was taken in October 2018, according to Bonilla's improved method [16]. Briefly, six citrus trees were selected for each treatment, and topsoil samples 
(10 30 cm depths) for each tree were collected at three different locations with a distance of $1.0 \mathrm{~m}$. Three samples from each tree were then mixed, screened $(2 \mathrm{~mm})$, and divided into two parts: one was air-dried for soil physical and chemical analysis; the rest were stored at $-80^{\circ} \mathrm{C}$ for DNA extraction and subsequent microbial community analysis.

\subsection{Soil Physicochemical Analyses}

The physicochemical analysis of all samples was repeated 6 times. Soil $\mathrm{pH}$ was determined using a glass electrode. Total organic matter (TOM) was determined using the $\mathrm{K}_{2} \mathrm{Cr}_{2} \mathrm{O}_{7}$ oxidation method [17]. Total nitrogen (TN) was determined by the semimicro Kjeldahl method, and total phosphorus (TP) and total potassium (TK) were digested by $\mathrm{HF}_{-} \mathrm{HClO}_{4}$ and determined by molybdenum-blue colorimetric and flame photometry, respectively [17]. Alkali-hydrolyzable nitrogen (AN) was analyzed using the alkaline diffusion method. Available potassium (AK) was extracted with ammonium acetate and determined with flame photometry. Available phosphorus (AP) was extracted with sodium bicarbonate and determined using the molybdenum blue method. The $\mathrm{NH}_{4}{ }^{+}-\mathrm{N}$ and $\mathrm{NO}_{3}{ }^{-}-\mathrm{N}$ concentrations of the soils were extracted with $2 \mathrm{~mol} \mathrm{~L}^{-1} \mathrm{KCl}$ and measured by a colorimetric method using a continuous-flow auto-analyzer (Auto Analyzer III, Bran Luebbe GmbH, Germany) [17].

\subsection{DNA Extraction and Illumina-Based Sequencing}

Soil total genomic DNA was extracted using MoBio Powersoil DNA extraction kit (MO BIO Laboratories, Inc., Carlsbad, CA, USA). The extracted DNA is purified using the MoBio PowerClean DNA Clean-Up Kit (MO BIO Laboratories, Inc., Carlsbad, CA, USA).

Soil bacterial community structure of citrus orchard was analyzed by Illumina MiSeq sequencing technology (18 samples in total, with 3 replicates for each treatment).

Bacterial 16S rRNA genes PCR amplicon primers were 515F (5'-GTGCCAGCMGCCG CGG-3') and 806R (5'-GGACTACHVGGGTWTCTAAT-3'), which targeted V4 hypervariable regions. PCR reaction systems were purified water $(13 \mu \mathrm{L})$, Prime Hot Master Mix $(10 \mu \mathrm{L})$, the forward and reverse primers $(0.5 \mu \mathrm{L}, 10 \mu \mathrm{M}$ final concentration), and genomic DNA $(1.0 \mu \mathrm{L})$. PCR reaction procedure was $95{ }^{\circ} \mathrm{C}$ for $5 \mathrm{~min}$, and 30 cycles of $94{ }^{\circ} \mathrm{C}$ for $30 \mathrm{~s}, 50^{\circ} \mathrm{C}$ for $60 \mathrm{~s}, 72{ }^{\circ} \mathrm{C}$ for $60 \mathrm{~s}$, and finally $72{ }^{\circ} \mathrm{C}$ for $10 \mathrm{~min}$. PCR product was purified using the MoBio UltraClean PCR Clean-Up Kit (MO BIO Laboratories, Inc., Carlsbad, CA, USA). The purified PCR product was stored at $-20{ }^{\circ} \mathrm{C}$ until sequenced. Illumina MiSeq sequencing was performed by Beijing Genomics Institute (NCBI accession number is SRP324073, and the Bioproject number is PRJNA737615).

\subsection{Sequences Data Analyses}

Sequencing reads were assigned to each sample based on its unique barcode of each sample, and the QIIME software package (Quantitative Insights Into Microbial Ecology) was used to analyze the sequences according to the UPARSE pipeline. The reads were filtered by QIIME quality filter, and the retained clean paired sequences were examined to pick up operational taxonomic units (OTUs) according to the OTU table. Briefly, the lower score quality sequences $(<0.5)$, shorter sequences $(<200)$, and chimeras were discarded, and the retained sequences belonged to OTUs with $97 \%$ similarity. A representative sequence was selected for each OTU, and the Ribosomal Database Project classifier was used to analyze the taxonomic data of each representative sequence. Rarefaction curves were generated based on the observed OTUs. Bacterial Shannon diversity index and weighted UniFrac distance based on phylogenetic information were calculated using QIIME (Version 1.8.0).

\subsection{Statistical Analysis}

An analysis of variance (ANOVA) was used to test the significance of the Shannon diversity index, soil physicochemical characteristics, and bacterial taxa abundance by SPSS 20 (IBM, Armonk, NY, USA). LSD-test in ANOVA was conducted to detect the 
difference between the different treatments in SPSS 20 (IBM, Armonk, NY, USA). $p<0.05$ was considered to be statistically significant. The bacterial species in the different nitrogen fertilization treatments were computed using the Vegan package in R 3.5.2. The correlations between microbial OTU composition (the top 100 OTUs) and the physicochemical factors were determined by CCA (Canonical correspondence analysis) by CANOCO 4.5. The relationship of bacteria community and environmental factor was established by the significance test of Monte Carlo permutation.

\section{Results}

\subsection{Citrus Yields and Soil Physicochemical Characteristics}

The field experiment results showed that excessive application of nitrogen fertilizer could not improve citrus yield. For example, the citrus yield in the N2 treatment was $40.12 \mathrm{~kg} \cdot$ tree $^{-1}$, considerably higher than N0 $\left(18.52 \mathrm{~kg} \cdot\right.$ tree $\left.^{-1}\right)$ and N5 $\left(21.25 \mathrm{~kg} \cdot\right.$ tree $\left.^{-1}\right)$ treatments (Figure 1). The nitrogen application rate significantly affected the soil physicochemical characteristics. The $\mathrm{pH}$ and TOM decreased with an increase in nitrogen fertilization (Figure 2A,B). Compared to the N0 treatment, $\mathrm{pH}$ and TOM in N5 treatment decreased by $44 \%$ and $19 \%$, respectively. Contrary to the trend of $\mathrm{pH}$ and $\mathrm{TOM}$, the contents of TN, AN, $\mathrm{NH}_{4}{ }^{+}-\mathrm{N}, \mathrm{TP}$, and $\mathrm{AP}$ were reduced with a decrease in nitrogen fertilization (Figure 2C-E,G,H). Compared to the N0 treatment, TN, AN, $\mathrm{NH}_{4}{ }^{+}-\mathrm{N}, \mathrm{TP}$, and AP in N5 treatment increased 30\%, 45\%,38\%, 26\%, and 131\%, respectively. The highest TK and AK were found in N3 treatment (Figure 2I,J), while the highest $\mathrm{NO}_{3}{ }^{-}-\mathrm{N}$ was found in $\mathrm{N} 2$ treatment (Figure $2 \mathrm{~F}$ ). In addition, the contents of $\mathrm{NO}_{3}{ }^{-}-\mathrm{N}$ did not show significant variations.

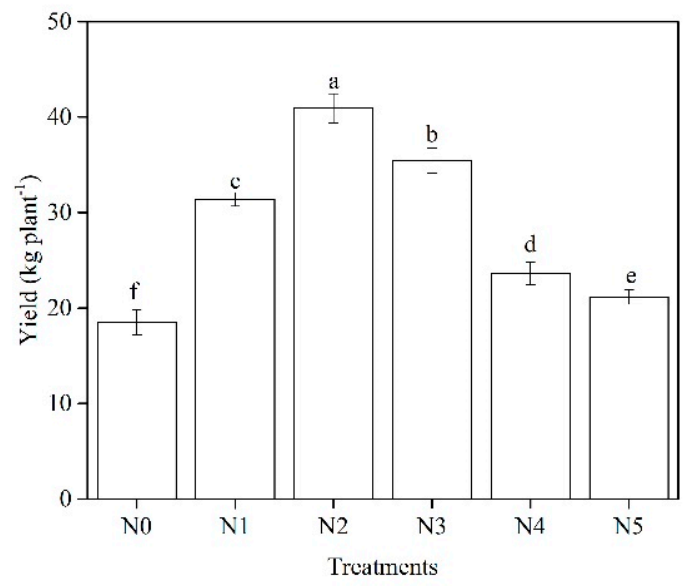

Figure 1. Citrus yields under different nitrogen fertilization treatments. Different letters indicate significant differences at $p<0.05$ level (ANOVA).

\subsection{Bacterial Diversity and Community Structures}

The Illumina MiSeq sequencing results showed that a total of 896,084 high-quality sequences (with an average length of $435 \mathrm{bp}$ ) were obtained, and the Shannon diversity curve was close to the plateau, indicating that the bacterial community of each sample was completely captured. The bacterial OTUs number ranged from 1164 to 1981 according to the $97 \%$ sequence similarity. Nitrogen fertilizer rate had a strong influence on bacterial Shannon diversity index, which showed an increase in bacterial diversity in N0 to N3 gradient and a decrease in bacterial diversity in N3 to N5 gradient (Table 1). N3 treatment showed the highest diversity, while the lowest diversities were observed in N0 treatment. The results of ANOVA analysis of the Shannon diversity index also show significant differences with $p$ value of 0.049 . 

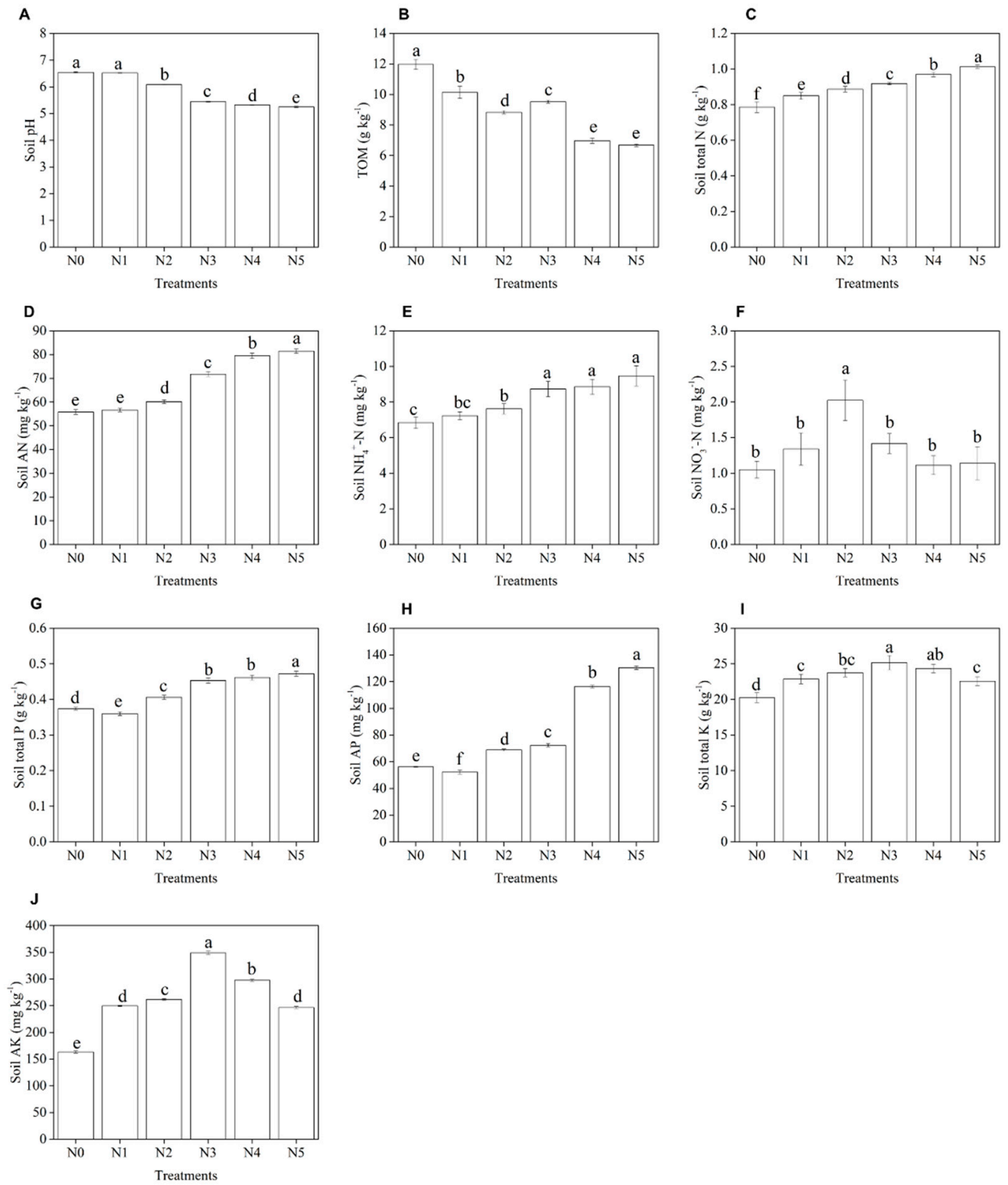

Figure 2. Physiochemical properties of the soil in different nitrogen fertilization treatments. Different letters indicate

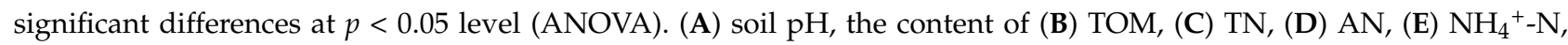
(F) $\mathrm{NO}_{3}{ }^{-}-\mathrm{N},(\mathrm{G}) \mathrm{TP},(\mathrm{H}) \mathrm{AP},(\mathrm{I}) \mathrm{TK}$ and (J) AK in the orchard soil.

Table 1. Soil bacterial $\alpha$-diversity indexes in different nitrogen fertilization treatments.

\begin{tabular}{ccc}
\hline Treatment & Shannon Diversity & Chao1 \\
\hline N0 & $5.93 \pm 0.24$ & $2158 \pm 97$ \\
N1 & $6.16 \pm 0.19$ & $2447 \pm 118$ \\
N2 & $6.35 \pm 0.26$ & $2589 \pm 87$ \\
N3 & $6.44 \pm 0.08$ & $2637 \pm 69$ \\
N4 & $6.28 \pm 0.11$ & $2507 \pm 128$ \\
N5 & $6.09 \pm 0.14$ & $2367 \pm 61$ \\
\hline
\end{tabular}

The values are the means of three replicates (means $\pm \mathrm{SD}$ ).

A total of 37 phyla, 88 classes, 170 orders, 318 families, and 549 genera were identified in our research, and an abundance of 15 phyla, 27 classes, 40 orders, 51 families, and 47 genera more than $0.5 \%$ (Table S1). Proteobacteria was the most dominant phylum 
(22.7-29.4\%) in all samples, followed by Actinobacteria (15.1-23.5\%), Chloroflexi (14.3-22.6\%), Acidobacteria (12.6-24.4\%), and Firmicutes (2.2-4.8\%) (Figures 3 and 4). The abundance of the top 10 phyla at each sampling site accounted for $93.1-97.1 \%$ of the total sequence, while the relative abundance of unclassified phyla was $0.4-1.1 \%$ (Table S1). Rhizobiales and Acidobacteriaceae-Subgroup 1 were the most dominant orders and family, with abundances of $5.5-12.3 \%$ and $2.2-13.8 \%$, respectively. The top 10 most abundant sequences of class, order, family, and genus accounted for $77,43,32$, and $19 \%$ of the total sequences, respectively (Figure 4$)$. Nitrospira was the most dominant genus $(0.2-8.4 \%)$, followed by Acidothermus (0.9-8.9\%), Solibacter (1.0-3.4\%), Bradyrhizobium (0.8-2.9\%), and Roseiflexus $(0.1-4.7 \%)$ (Figure 4$)$.

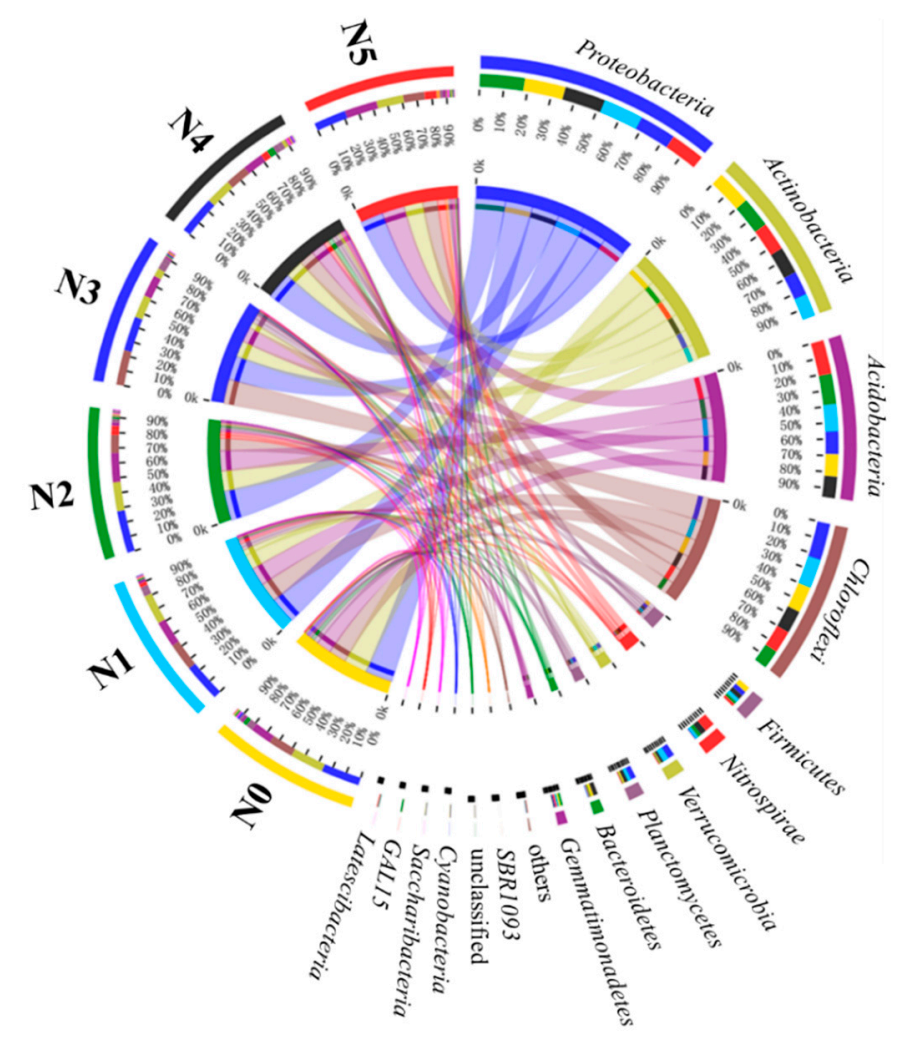

Figure 3. The relative abundance of 15 major bacterial phyla in the different nitrogen fertilization treatments.

\subsection{Changes in the Bacterial Community Composition in Response to Nitrogen Gradient}

Nitrogen application rate had a significant effect on the bacterial taxa distribution; as shown in Figure 5 and Table 2, the relative abundances of Delta-proteobacteria, Nitrospirae, SBR1093, and Latescibacteria were reduced with a decrease in nitrogen fertilization, and a reversed pattern was observed for Alpha-proteobacteria. The finer taxonomic division also showed the significant effect of nitrogen application rate (Figure 5). For example, Frankiales (within Actinobacteria), Rhodospirillales (within Alpha-proteobacteria), and JG30-KFAS9 (within Ktedonobacteria) increased their abundance with lowering nitrogen fertilization (Table 2). Similarly, the abundance of Bradyrhizobiaceae, DA111 (within Alpha-proteobacteria), and Acidothermaceae (within Actinobacteria) showed an obvious decrease from N0 to N5 treatment (Table 2). Further taxonomic analyses showed that, in the genus level, Acidothermus (within Actinobacteria), Bradyrhizobium (within Alpha-proteobacteria), and Bryobacter (within Acidobacteria) had the strongest dependence on nitrogen fertilization, with a significantly higher abundance in N0 than in any other treatments (Table 2). Finally, 5 bacterial phylum and subphyla, and 17 bacterial under-taxonomies, exhibited a significant correlation with nitrogen application rate (Table 2). 


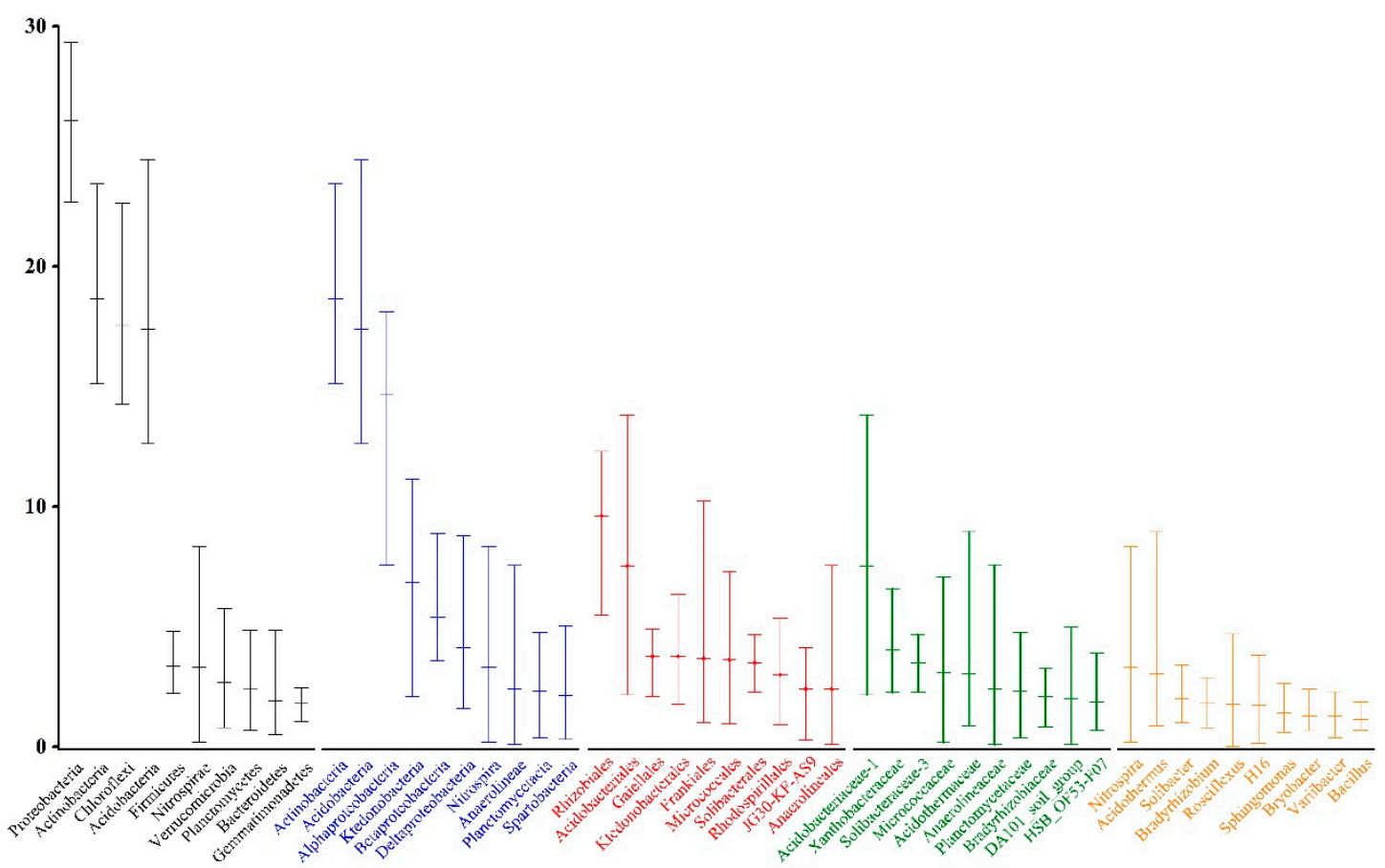

Figure 4. The relative abundance of the top-10 bacterial taxa at the phyla (black), class (blue), order (red), family(green), and genus (yellow) levels for all samples.

Table 2. The Pearson's correlation analysis of bacteria abundance and nitrogen fertilization gradient. ${ }^{*}$ and ${ }^{* *}$ indicate significant correlations at $p<0.05$ and $p<0.01$, respectively.

\begin{tabular}{|c|c|c|}
\hline Phylum and Subphyla & Taxonomy & $R$ \\
\hline Alpha-proteobacteria & $\begin{array}{c}\text { Rhodospirillales (order) } \\
\text { Bradyrhizobiaceae (family) } \\
\text { DA111 (family) } \\
\text { Bradyrhizobium (genus) } \\
\text { Rhizomicrobium (genus) }\end{array}$ & $\begin{array}{l}-0.79 * \\
-0.87^{* *} \\
-0.83^{*} \\
-0.92^{* *} \\
-0.84^{*} \\
-0.86^{*}\end{array}$ \\
\hline Delta-proteobacteria & $\begin{array}{l}\text { Desulfurellales (order) } \\
\text { Desulfurellaceae (family) }\end{array}$ & $\begin{array}{l}0.80 * \\
0.79 * \\
0.79 *\end{array}$ \\
\hline Gamma-proteobacteria & Acidibacte (genus) & $-0.89 * *$ \\
\hline Nitrospirae & Nitrospira (class) & $\begin{array}{l}0.79 * \\
0.79 *\end{array}$ \\
\hline SBR1093 & & $0.81 *$ \\
\hline Latescibacteria & & $0.78 *$ \\
\hline Chloroflexi & $\begin{array}{l}\text { Ktedonobacteria (class) } \\
\text { JG30-KF-AS9 (order) }\end{array}$ & $\begin{array}{l}-0.82 * \\
-0.88 * *\end{array}$ \\
\hline Actinobacteria & $\begin{array}{c}\text { Frankiales (order) } \\
\text { Acidothermaceae (family) } \\
\text { Elev-16S-1332 (family) } \\
\text { Acidothermus (genus) }\end{array}$ & $\begin{array}{l}-0.86 * \\
-0.85 * \\
0.90 * * \\
-0.85 *\end{array}$ \\
\hline Firmicutes & Halanaerobiales (order) & $-0.81 *$ \\
\hline Acidobacteria & Bryobacter (genus) & $-0.95^{* *}$ \\
\hline
\end{tabular}




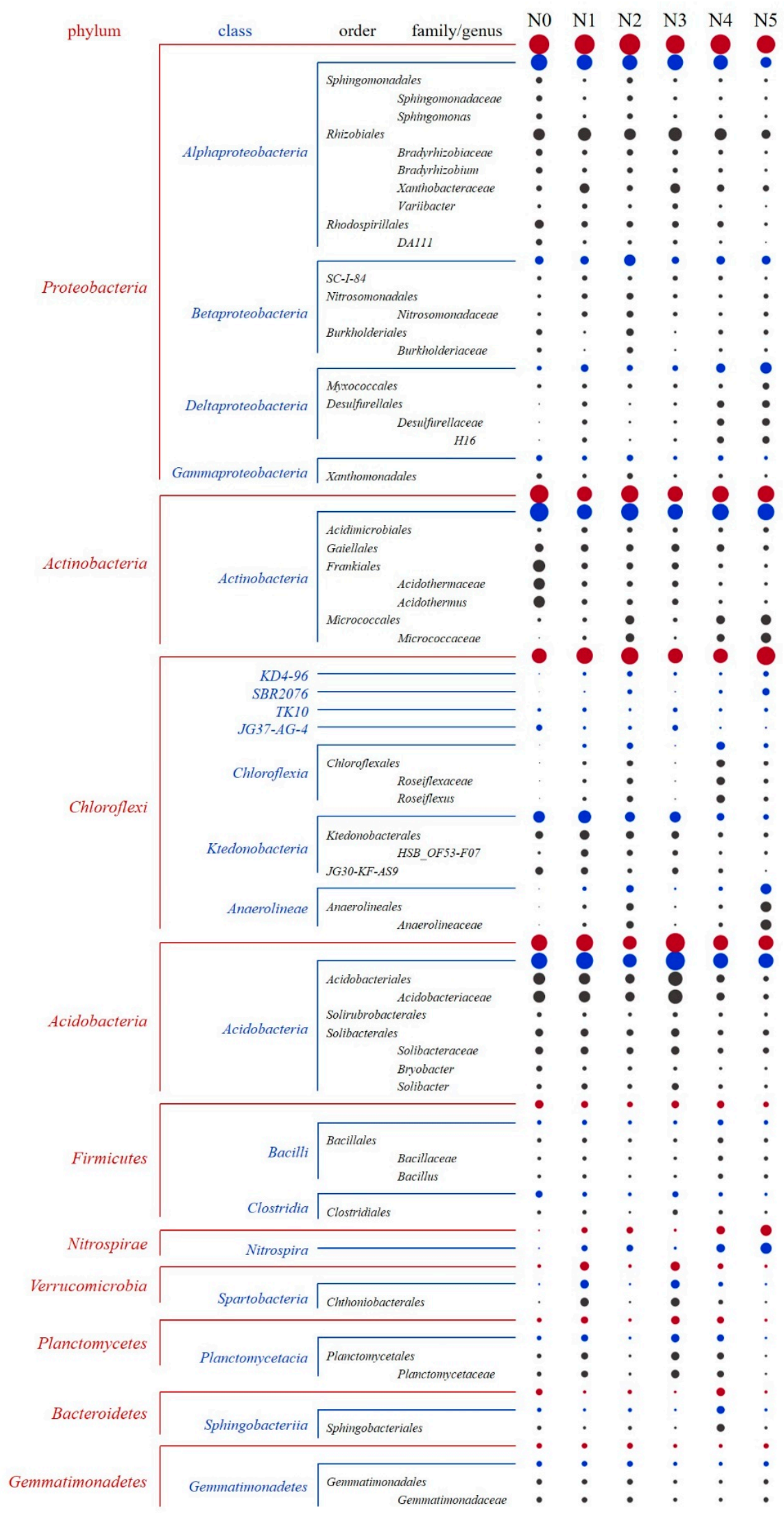

Figure 5. The response of bacterial community structure in different taxonomical levels to nitrogen gradient (only shown the sequence of bacteria $>1 \%$ of all sequences). The size of the circle represented the relative abundance of bacteria at each treatment, and the color of the circle represents bacterial taxonomical levels: red is phylum; blue is class; black is order, family, and genus. 


\subsection{Correlations between Bacterial Community and Soil Properties}

The results of CCA (Figure 6) reveal that the bacterial community composition was associated with four environmental factors: AN, AP, TN, and TOM $(p<0.01,999$ Monte Carlo permutations). The first two axes of CCA could explain $37.7 \%$ and $19.0 \%$ of the total variation. Two types of bacterial community distribution were observed corresponding to $\mathrm{N} 0 / \mathrm{N} 1 / \mathrm{N} 3$ and $\mathrm{N} 4 / \mathrm{N} 5$, but individual sites appeared to have a stand-alone community in $\mathrm{N} 2$.

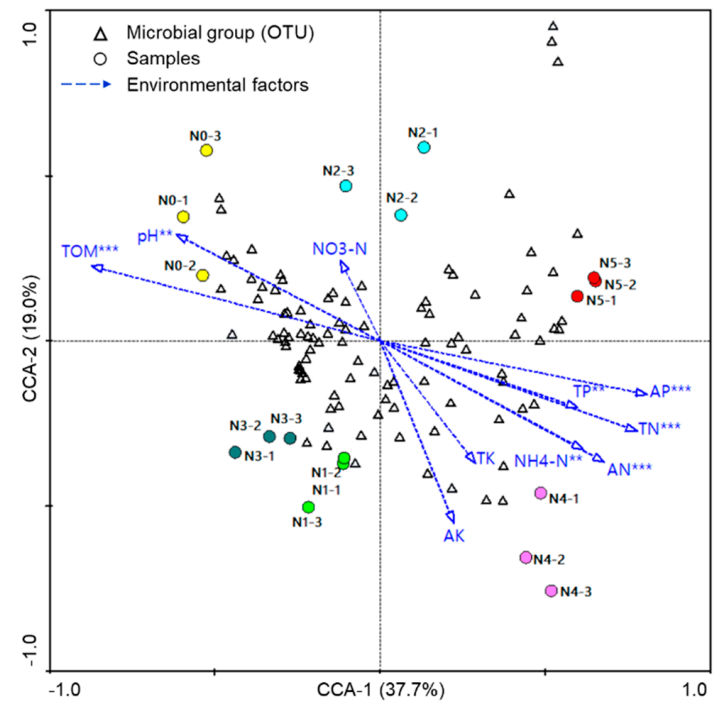

Figure 6. Canonical correspondence analysis (CCA) ordination diagram of bacterial communities associated with environmental variables based on Illumina MiSeq sequencing of the 18 samples in the 6 treatments. ${ }^{* *}$ and ${ }^{* * *}$ indicate significant correlations at $p<0.01$ and $p<0.001$, respectively.

\subsection{Relationship between Bacterial Taxa and Citrus Yields}

Regression analysis between bacterial abundance and citrus yields revealed that the bacterial taxa were significantly correlated to citrus yields (Figure 7). A significantly positive correlation between citrus yields and the relative abundance of Nitrosomonadales $\left(R^{2}=0.60, p<0.001\right)$, Rhodobiaceae $\left(R^{2}=0.62, p<0.001\right)$, Gemmatimonas $\left(R^{2}=0.68, p<0.001\right)$, and Variibacter $\left(R^{2}=0.69, p<0.001\right)$ was observed. In addition, this study also found that there was a strong positive correlation between bacterial diversity and citrus yield (Figure 8).

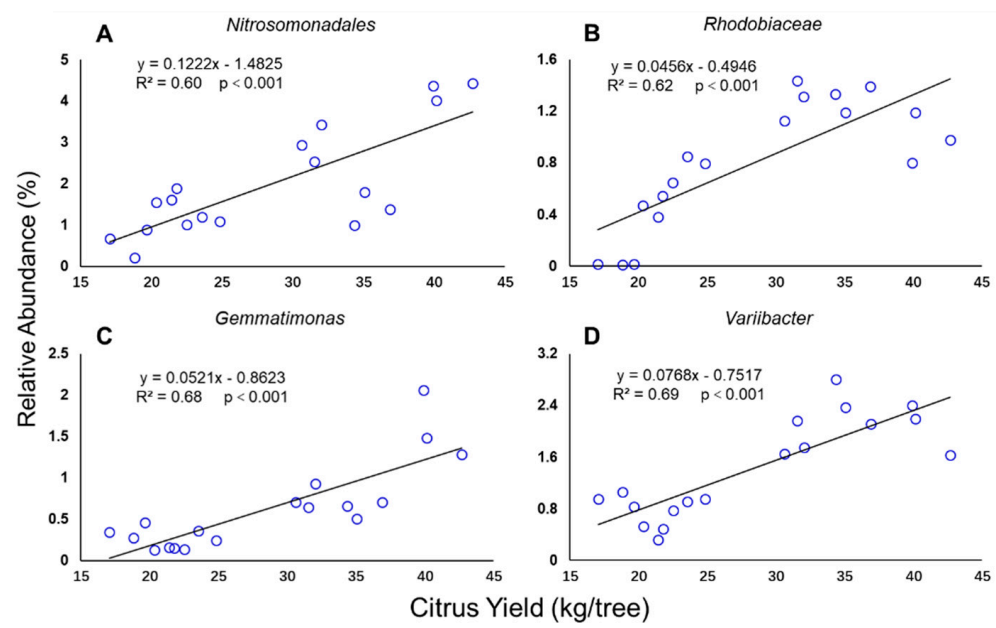

Figure 7. Relationships between citrus yields and the relative abundance of bacterial taxa (A-D). Solid lines are regression fitting curves between citrus yields and the relative abundance of each bacterial taxa. 


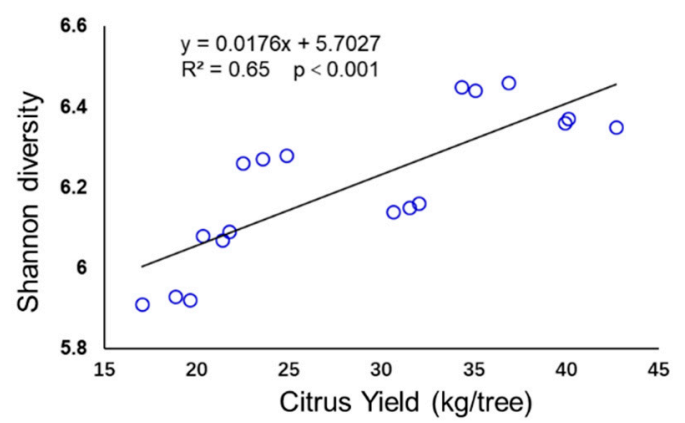

Figure 8. Relationships between citrus yields and Shannon diversity.

\section{Discussion}

\subsection{Effects of Nitrogen Fertilization on Citrus Yield}

There was great variation of the nitrogen requirements among different cultivars citrus. For example, the high-yielding nitrogen application rate of blood orange was $0.67 \mathrm{~kg} \cdot \mathrm{N} \cdot$ tree $^{-1} \cdot$ year $^{-1}$ in this study, which was consistent with Valencia orange $\left(0.68 \mathrm{~kg} \cdot \mathrm{N}\right.$ tree ${ }^{-1} \cdot$ year $\left.^{-1}\right)$, higher than sekken $\left(0.5 \mathrm{~kg} \cdot \mathrm{N} \cdot\right.$ tree $^{-1} \cdot$ year $\left.^{-1}\right)$, and much lower than sweet orange $\left(1.60 \mathrm{~kg} \cdot \mathrm{N} \cdot\right.$ tree $\left.^{-1} \cdot \mathrm{year}^{-1}\right)$ [18]. Within a certain range of nitrogen fertilizer rates, appropriate increase of nitrogen fertilizer could help to increase citrus yield. For example, within a range of $150-450 \mathrm{~kg} \cdot \mathrm{N} \cdot \mathrm{hm}^{-2}$, a positive correlation between nitrogen application rate and Valencia orange yield was observed [18]. Further studies showed that excessive nitrogen fertilizer application could reduce citrus yield. For example, over nitrogen application rate of $0.68 \mathrm{~kg} \cdot \mathrm{N}$ tree $^{-1} \cdot \mathrm{year}^{-1}$ would cause the reduction of Valencia orange yield [18]. Moreover, excessive application of nitrogen fertilizer would lead to the decline of nutrient absorption and fertilizer utilization rate of fruit trees, which caused a series of environmental problems such as water eutrophication and soil acidification [19]. It is thus reasonable to suggest that rational fertilization can reduce the non-point source pollution and increase citrus yield.

\subsection{Bacterial Community Structure Characteristics}

Proteobacteria, Actinobacteria, Chloroflexi, and Acidobacteria were the dominant phyla in our study, similar to other research on orchard soil [20] but distinct from research on vegetable [21] and crop soil [22]. Such pattern might be due to the difference of planting patterns. It was known that the phylum Proteobacteria dominated in various soil environments, including alkaline/acidic and nutrient-limited/abundant systems, and it played an important role in the biogeochemical processes of agroecosystem [23]. For example, numerous studies have shown the predominance of Proteobacteria in the soil of planting crops, fruits, and vegetables, with large changes in the major classes composition and its relative abundance [24,25]. At the class level, Delta-proteobacteria [26] and Betaproteobacteria [27] were observed to occur in nutrient rich soil. Alpha-proteobacteria occurred almost exclusively in agroecological environments and was considered to be the dominant group in the organic matter rich soil [25].

Nitrospira, Acidothermus, Solibacter, Bradyrhizobium, and Roseiflexus were the most dominant genera, and played an important role in biogeochemical cycles. Nitrospira genera are representatives of nitrite-oxidizing bacteria; some of the strains of Nitrospira genus can grow as mixotrophs and heterotrophs [28]. The acidophilic genus Acidothermus was predominantly found in the acid soil [29]. Solibacter genera were involved in the degradation of complex organic compounds, and were able to degrade more recalcitrant organic material as plants grow [30]. It has been suggested that Bradyrhizobium genera were the relatively abundant genera in the cultivated soils, and had the nitrate and nitrite reduction pathways in their metabolisms [31]. Genera Roseiflexus significantly increased with an increase in heavy metal pollution degree, and alternated between heterotrophic and photosynthetic metabolism [32,33]. 


\subsection{Responses of Bacterial Taxa and Biodiversity to Nitrogen Fertilization Gradient}

Sequencing analysis indicated that, at the phylum, class, and order level, Deltaproteobacteria, Nitrospirae, Latescibacteria, and SBR1093 showed a significant positive correlation with nitrogen application rate, while Alpha-proteobacteria, Ktedonobacteria, JG30-KF-AS9, Frankiales, and Halanaerobiales exhibited the opposite trend (Table 2). The differences in bacterial community composition following nitrogen application were previously explained by the copiotrophic hypothesis, in which copiotrophic bacterial taxa (e.g., Delta-proteobacteria, Latescibacteria, and SBR1093) were more likely to have fast growth rates in nutrient-rich conditions [34,35], while oligotrophic bacterial taxa (e.g., Gamma-proteobacteria, Acidobacteria, Firmicutes, and Chloroflexi) grew slower in nutrient-poor conditions [25,36,37]. However, in our research, some copiotrophic organisms such as Alpha-proteobacteria are negatively correlated with nitrogen application rate (Table 2). This varied response was also observed in previous research that nitrogen enrichment led to an abundance of Alpha-proteobacteria in grassland but showed a negative correlation with nitrogen enrichment in agricultural fields [38] and planted forests [26]. Interestingly, bacteria belonging to the same taxonomy responded to nitrogen enrichment in a different pattern. For example, Elev-16S-1332, which responded to nitrogen enrichment, was different from other bacterial taxa of phylum Actinobacteria. Bacteria in the taxa of Actinobacteria's response to nitrogen addition was frequently inconsistent, along with previous studies in a steppe ecosystem [39], which means that both nitrogen-added-amount and treatment duration might affect response [40]. Nitrospirae played an important role in the nitrite oxidation in soil, and consequently these bacteria could flourish in high nitrogen gradient. Additionally, the more the contents of $\mathrm{NH}_{4}{ }^{+}-\mathrm{N}$ increased with increasing nitrogen fertilization, the more the contents of $\mathrm{NH}_{4}{ }^{+}-\mathrm{N}$ promoted the growth of Nitrospira. Because the metabolism of this bacteria required $\mathrm{NH}_{4}{ }^{+}-\mathrm{N}$ input, higher abundances of Nitrospira contributed to higher $\mathrm{NH}_{4}{ }^{+}-\mathrm{N}$ transformation efficiencies [41].

Our results showed that nitrogen fertilization increased bacterial diversity in N0 to N3 gradient, whereas it decreased bacterial diversity in N3 to N5 gradient. Zhang and Zak (1998) found that nitrogen fertilization improved microbial biodiversity and root growth [42]. Moreover, it has been found that bacterial biodiversity might act as a significant short-term sink for available nitrogen, and nitrogen fertilization addition could promote the rise of microbial nitrogen [43]. In contrast, the application of nitrogen fertilizer decreased bacterial diversity as described by others [39,44]. The change of bacterial diversity in the high nitrogen application rate was previously explained by the mechanism, in which the establishment of a toxic osmotic potential by nitrogen fertilizer addition in a closed environment might lead to inhibit microbial biodiversity and activity [45].

\subsection{Bacterial Community Structures Influencing Factors}

Consistent with previous studies in other orchard soil [25,46,47], CCA results from our analyses (Figure 6) showed that AN, AP, TN, and TOM $(p<0.001)$, as well as $\mathrm{pH}$, $\mathrm{TP}$, and $\mathrm{NH}_{4}{ }^{+} \mathrm{N}(p<0.01)$, are likely the main environmental factors affecting bacterial community compositions.

Soil bacterial composition was often related to soil $\mathrm{pH}$, even at large scales. The narrow $\mathrm{pH}$ range for optimal growth of bacteria might be the main factor affecting bacterial community composition $[48,49]$. In addition, soil acidification could lead to changes in nutrient availability, such as phosphorus, magnesium, and potassium, which might indirectly affect soil microbial communities [50]. Previous research indicated soil bacterial diversity and community structure were shaped more by changes in soil $\mathrm{pH}$ rather than the direct effect of nutrient addition [24]. Soil $\mathrm{pH}$ was the main driving factor for different soil management and land use types, but the effect of nitrogen fertilizer on soil nitrogen availability directly affected soil bacterial community composition [48,51]. Ramirez et al., (2010) observed that, regardless of soil and nitrogen fertilizer type, nitrogen fertilizer availability had a significant influence on microbial respiration [52]. However, other factors might also cause the soil bacterial community to respond to the changes in nitrogen 
addition. Cusack et al., (2011) found that the changes of soil organic matter quantity and quality after nitrogen enrichment were related to the changes of soil microbial community and related enzyme activities [53].

\subsection{Bacterial Taxa Related to Citrus Yields}

Five bacterial taxa were correlated positively with citrus yields, which might be an indication that these microbes played a crucial role in the growth of plants and the prevention of diseases. Gemmatimonas was a polyphosphate-accumulating organism for plant-absorbing essential phosphorus in nutrient-deficient areas [54]. Moreover, recent research showed that Gemmatimonas was significantly elevated in bio-organic fertilizertreated soil compared to other soil samples in the banana orchard and exhibited a strong negative correlation with disease incidence, indicating that Gemmatimonas might respond to the suppression of Fusarium wilt disease via bio-organic fertilizer application [55]. Yin et al., (2013) reported that the Gemmatimonas were more abundant in the rhizosphere of healthy wheat, suggesting Gemmatimonas was a kind of biocontrol agent that can protect plants from diseases caused by pathogenic microorganisms [56]. Variibacter and Rhodobiaceae belong to order Rhizobiales, which was a controller at the hub of the ecosystem nitrogen cycle and often facilitated atmospheric nitrogen fixation by plants [57]. In addition, previous studies indicated that Rhodobiaceae played an important role in fixing molecular nitrogen and was related to soil organic carbon and nitrogen accumulation [58]. Nitrosomonadales was the typical ammonia-oxidizing bacteria, which was mainly responsible for the oxidation of ammonia to nitrate [59]. Previous research found that the addition of Nitrosomonadales could reduce nitrogen loss, as well as the time required to stabilize the nitrogen profile [60]. Additionally, some bacteria in the taxa of Nitrosomonadales were useful for biotechnological processes such as bioremediation of toxic chemicals in the soil [61].

\section{Conclusions}

A high-throughput Illumina MiSeq sequencing method was used to investigate the bacterial community structure and diversity in citrus orchard soil. More than 890,000 sequences were examined in the orchard soil environment to assess the effect of a long-term nitrogen fertilization gradient on the bacterial community, and the results showed that 22 bacterial taxa were significantly correlated with the nitrogen fertilization gradient. The results of this study were summarized as follows:

(1) Nitrogen fertilizer addition increased the contents of $\mathrm{TN}, \mathrm{AN}, \mathrm{NH}_{4}{ }^{+}-\mathrm{N}, \mathrm{TP}$, and $\mathrm{AP}$ but decreased $\mathrm{pH}$ and TOM along the $\mathrm{N} 0$ to $\mathrm{N} 5$ gradient.

(2) The bacterial diversity was positively related to nitrogen fertilizer along the N0 to N3 gradient but was inversely related to nitrogen fertilizer along the N3 to N5 gradient.

(3) Under the long-term nitrogen fertilization gradient, the major environmental factors affecting the bacterial community were AN, AP, TN, and TOM.

(4) The abundance of Nitrosomonadales, Rhodobiaceae, Gemmatimonas, and Variibacter was correlated positively with citrus yield.

Supplementary Materials: The following are available online at https:/ / www.mdpi.com/article/10 .3390/d13070282/s1, Table S1: All OTU counts and taxonomy in nitrogen fertilizer gradient treatment.

Author Contributions: Conceptualization, Y.W. and J.W.; methodology, Y.W. and X.S.; software, Y.W.; validation, W.L.; formal analysis, Y.W. and W.L.; investigation, Y.W. and J.W.; resources, X.S.; data curation, J.W. and X.S.; writing—original draft preparation, Y.W.; writing-review and editing, Y.W. and X.S.; visualization, W.L.; supervision, X.S.; project administration, Y.W. and W.L.; funding acquisition, W.L. All authors have read and agreed to the published version of the manuscript.

Funding: This research was supported by Natural Science Foundation of Chongqing, China (cstc2019jcyj-bshX0007), National Natural Science Foundation of China (31801932), and Science and Technology Project from Chongqing Urban Administration (2020).

Institutional Review Board Statement: Not applicable. 
Informed Consent Statement: Not applicable.

Data Availability Statement: The data that support the findings of this study are available from the Supplementary Table S1 and NCBI database under the BioProject ID code PRJNA737615, and accession number SRP324073.

Acknowledgments: This research was supported by the National Natural Science Foundation of China, Natural Science Foundation of Chongqing, China, and Science and Technology Project from Chongqing Urban Administration.

Conflicts of Interest: The authors declare no conflict of interest.

\section{References}

1. Singh, J.S.; Pandey, V.C.; Singh, D.P. Efficient soil microorganisms: A new dimension for sustainable agriculture and environmental development. Agric. Ecosyst. Environ. 2011, 140, 339-353. [CrossRef]

2. Lugtenberg, B.; Kamilova, F. Plant-growth-promoting rhizobacteria. Annu. Rev. Microbiol. 2009, 63, 541-556. [CrossRef]

3. Franke-Whittle, I.H.; Manici, L.M.; Insam, H.; Stres, B. Rhizosphere bacteria and fungi associated with plant growth in soils of three replanted apple orchards. Plant Soil 2015, 395, 317-333. [CrossRef]

4. Zhou, X.X.; He, Z.L.; Liang, Z.B.; Stoffella, P.J.; Fan, J.H.; Yang, Y.G.; Powell, C.A. Long-Term Use of Copper-Containing Fungicide Affects Microbial Properties of Citrus Grove Soils. Soil Sci. Soc. Am. J. 2011, 75, 898-906. [CrossRef]

5. Xue, D.; Huang, X.D.; Yao, H.Y.; Huang, C.Y. Effect of lime application on microbial community in acidic tea orchard soils in comparison with those in wasteland and forest soils. J. Environ. Sci. 2010, 22, 1253-1260. [CrossRef]

6. Zhong, W.H.; Cai, Z.C. Long-term effects of inorganic fertilizers on microbial biomass and community functional diversity in a paddy soil derived from quaternary red clay. Appl. Soil Ecol. 2007, 36, 84-91. [CrossRef]

7. Chu, H.; Fujii, T.; Morimoto, S.; Lin, X.; Yagi, K.; Hu, J.; Zhang, J. Community structure of ammonia-oxidizing bacteria under long-term application of mineral fertilizer and organic manure in a sandy loam soil. Appl. Environ. Microbiol. 2007, 73, 485-491. [CrossRef]

8. Sarathchandra, S.; Ghani, A.; Yeates, G.; Burch, G.; Cox, N. Effect of nitrogen and phosphate fertilisers on microbial and nematode diversity in pasture soils. Soil Biol. Biochem. 2001, 33, 953-964. [CrossRef]

9. He, J.Z.; Shen, J.P.; Zhang, L.M.; Zhu, Y.G.; Zheng, Y.M.; Xu, M.G.; Di, H. Quantitative analyses of the abundance and composition of ammonia-oxidizing bacteria and ammonia-oxidizing archaea of a Chinese upland red soil under long-term fertilization practices. Environ. Microbiol. 2007, 9, 2364-2374. [CrossRef]

10. National Bureau of Statistics. China Statistical Yearbook 2019; China Statistics Press: Beijing, China, 2019.

11. National Bureau of Statistics. China Statistical Yearbook 2016; China Statistics Press: Beijing, China, 2016.

12. Xu, J.; Zhang, Y.; Zhang, P.; Trivedi, P.; Riera, N.; Wang, Y.; Liu, X.; Fan, G.; Tang, J.; Coletta-Filho, H.D.; et al. The structure and function of the global citrus rhizosphere microbiome. Nat. Commun. 2018, 9, 4894. [CrossRef]

13. Wu, B.; Wang, P.; Devlin, A.T.; Xiao, S.; Shu, W.; Zhang, H.; Ding, M. Influence of Soil and Water Conservation Measures on Soil Microbial Communities in a Citrus Orchard of Southeast China. Microorganisms 2021, 9, 319. [CrossRef]

14. Wu, Y.; Qu, M.; Pu, X.; Lin, J.; Shu, B. Distinct microbial communities among different tissues of citrus tree Citrus reticulata cv. Chachiensis. Sci. Rep. 2020, 10, 1-9. [CrossRef]

15. Munir, S.; Li, Y.; He, P.; Huang, M.; He, P.; He, P.; Cui, W.; Wu, Y.; He, Y. Core endophyte communities of different citrus varieties from citrus growing regions in China. Sci. Rep. 2020, 10, 1-12. [CrossRef] [PubMed]

16. Bonilla, N.; Cazorla, F.M.; Martinez-Alonso, M.; Hermoso, J.M.; Gonzalez-Fernandez, J.J.; Gaju, N.; Landa, B.B.; de Vicente, A. Organic amendments and land management affect bacterial community composition, diversity and biomass in avocado crop soils. Plant Soil 2012, 357, 215-226. [CrossRef]

17. Lu, R.K. Methods of Soil and Agrochemical Analyses; China Agricultural Science and Technology Press: Beijing, China, 2000.

18. Alva, A.K.; Paramasivam, S.; Obreza, T.A.; Schumann, A.W. Nitrogen best management practice for citrus trees: I. Fruit yield, quality, and leaf nutritional status. Sci. Hortic. 2006, 109, 223-233. [CrossRef]

19. Tian, D.; Niu, S. A global analysis of soil acidification caused by nitrogen addition. Environ. Res. Lett. 2015, 10, 024019. [CrossRef]

20. Zhang, Q.; Sun, J.; Liu, S.; Wei, Q. Manure refinement affects apple rhizosphere bacterial community structure: A study in sandy soil. PLoS ONE 2013, 8, e76937. [CrossRef]

21. Tian, W.; Zhang, Z.; Hu, X.; Tian, R.; Zhang, J.; Xiao, X.; Xi, Y. Short-term changes in total heavy metal concentration and bacterial community composition after replicated and heavy application of pig manure-based compost in an organic vegetable production system. Biol. Fertil. Soils 2015, 51, 593-603. [CrossRef]

22. Kavamura, V.N.; Hayat, R.; Clark, I.M.; Rossmann, M.; Mendes, R.; Hirsch, P.R.; Mauchline, T.H. Inorganic Nitrogen Application Affects Both Taxonomical and Predicted Functional Structure of Wheat Rhizosphere Bacterial Communities. Front. Microbiol. 2018, 9, 1074. [CrossRef]

23. Dai, Z.; Su, W.; Chen, H.; Barberan, A.; Zhao, H.; Yu, M.; Yu, L.; Brookes, P.C.; Schadt, C.W.; Chang, S.X.; et al. Long-term nitrogen fertilization decreases bacterial diversity and favors the growth of Actinobacteria and Proteobacteria in agro-ecosystems across the globe. Glob. Chang. Biol. 2018, 24, 3452-3461. [CrossRef] 
24. Zhang, Y.; Shen, H.; He, X.; Thomas, B.W.; Lupwayi, N.Z.; Hao, X.; Thomas, M.C.; Shi, X. Fertilization Shapes Bacterial Community Structure by Alteration of Soil pH. Front. Microbiol. 2017, 8, 1325. [CrossRef]

25. Wang, L.; Li, J.; Yang, F.; Yaoyao, E.; Raza, W.; Huang, Q.W.; Shen, Q.R. Application of Bioorganic Fertilizer Significantly Increased Apple Yields and Shaped Bacterial Community Structure in Orchard Soil. Microb. Ecol. 2017, 73, 404-416. [CrossRef] [PubMed]

26. Liu, G.Y.; Chen, L.L.; Shi, X.R.; Yuan, Z.Y.; Yuan, L.Y.; Lock, T.R.; Kallenbach, R.L. Changes in rhizosphere bacterial and fungal community composition with vegetation restoration in planted forests. Land Degrad. Dev. 2019, 30, 1147-1157. [CrossRef]

27. Fierer, N.; Bradford, M.A.; Jackson, R.B. Toward an ecological classification of soil bacteria. Ecology 2007, 88, 1354-1364. [CrossRef]

28. Attard, E.; Poly, F.; Commeaux, C.; Laurent, F.; Terada, A.; Smets, B.F.; Recous, S.; Roux, X.L. Shifts between Nitrospiraand Nitrobacter-like nitrite oxidizers underlie the response of soil potential nitrite oxidation to changes in tillage practices. Environ. Microbiol. 2010, 12, 315-326. [CrossRef] [PubMed]

29. Sun, B.; Wang, F.; Jiang, Y.; Li, Y.; Dong, Z.; Li, Z.; Zhang, X.X. A long-term field experiment of soil transplantation demonstrating the role of contemporary geographic separation in shaping soil microbial community structure. Ecol. Evol. 2014, 4, 1073-1087. [CrossRef]

30. Rime, T.; Hartmann, M.; Brunner, I.; Widmer, F.; Zeyer, J.; Frey, B. Vertical distribution of the soil microbiota along a successional gradient in a glacier forefield. Mol. Ecol. 2015, 24, 1091-1108. [CrossRef]

31. Cao, X.; Diao, M.; Zhang, B.; Liu, H.; Wang, S.; Yang, M. Spatial distribution of vanadium and microbial community responses in surface soil of Panzhihua mining and smelting area, China. Chemosphere 2017, 183, 9-17. [CrossRef]

32. Hong, C.; Si, Y.; Xing, Y.; Li, Y. Illumina MiSeq sequencing investigation on the contrasting soil bacterial community structures in different iron mining areas. Environ. Sci. Pollut. Res. Int. 2015, 22, 10788-10799. [CrossRef]

33. Lucheta, A.R.; Otero, X.L.; Macias, F.; Lambais, M.R. Bacterial and archaeal communities in the acid pit lake sediments of a chalcopyrite mine. Extremophiles 2013, 17, 941-951. [CrossRef]

34. Fu, X.; Wang, J.; Sainju, U.M.; Zhao, F.Z.; Liu, W.Z. Soil microbial community and carbon and nitrogen fractions responses to mulching under winter wheat. Appl. Soil Ecol. 2019, 139, 64-68. [CrossRef]

35. Wang, Z.; Guo, F.; Liu, L.; Zhang, T. Evidence of carbon fixation pathway in a bacterium from candidate phylum SBR1093 revealed with genomic analysis. PLoS ONE 2014, 9, e109571. [CrossRef] [PubMed]

36. Moreno-Letelier, A.; Olmedo, G.; Eguiarte, L.E.; Martinez-Castilla, L.; Souza, V. Parallel Evolution and Horizontal Gene Transfer of the pst Operon in Firmicutes from Oligotrophic Environments. Int. J. Evol. Biol. 2011, 2011, 781642. [CrossRef] [PubMed]

37. Cho, J.C.; Stapels, M.D.; Morris, R.M.; Vergin, K.L.; Schwalbach, M.S.; Givan, S.A.; Barofsky, D.F.; Giovannoni, S.J. Polyphyletic photosynthetic reaction centre genes in oligotrophic marine Gammaproteobacteria. Environ. Microbiol. 2007, 9, 1456-1463. [CrossRef] [PubMed]

38. Fierer, N.; Lauber, C.L.; Ramirez, K.S.; Zaneveld, J.; Bradford, M.A.; Knight, R. Comparative metagenomic, phylogenetic and physiological analyses of soil microbial communities across nitrogen gradients. ISME J. 2012, 6, 1007-1017. [CrossRef]

39. Zeng, J.; Liu, X.J.; Song, L.; Lin, X.G.; Zhang, H.Y.; Shen, C.C.; Chu, H.Y. Nitrogen fertilization directly affects soil bacterial diversity and indirectly affects bacterial community composition. Soil Biol. Biochem. 2016, 92, 41-49. [CrossRef]

40. Janssens, I.A.; Dieleman, W.; Luyssaert, S.; Subke, J.A.; Reichstein, M.; Ceulemans, R.; Ciais, P.; Dolman, A.J.; Grace, J.; Matteucci, G.; et al. Reduction of forest soil respiration in response to nitrogen deposition. Nat. Geosci. 2010, 3, 315-322. [CrossRef]

41. Hamilton, T.L.; Koonce, E.; Howells, A.; Havig, J.R.; Jewell, T.; de la Torre, J.R.; Peters, J.W.; Boyd, E.S. Competition for ammonia influences the structure of chemotrophic communities in geothermal springs. Appl. Environ. Microbiol. 2014, 80, 653-661. [CrossRef]

42. Zhang, Q.H.; Zak, J.C. Effects of water and nitrogen amendment on soil microbial biomass and fine root production in a semi-arid environment in West Texas. Soil Biol. Biochem. 1998, 30, 39-45. [CrossRef]

43. Fisk, M.C.; Schmidt, S.K. Microbial responses to nitrogen additions in alpine tundra soil. Soil Biol. Biochem. 1996, 28, 751-755. [CrossRef]

44. Campbell, B.J.; Polson, S.W.; Hanson, T.E.; Mack, M.C.; Schuur, E.A. The effect of nutrient deposition on bacterial communities in Arctic tundra soil. Environ. Microbiol. 2010, 12, 1842-1854. [CrossRef]

45. Thirukkumaran, C.M.; Parkinson, D. Microbial respiration, biomass, metabolic quotient and litter decomposition in a lodgepole pine forest floor amended with nitrogen and phosphorous fertilizers. Soil Biol. Biochem. 2000, 32, 59-66. [CrossRef]

46. Cui, H.; Zhou, Y.; Gu, Z.H.; Zhu, H.H.; Fu, S.L.; Yao, Q. The combined effects of cover crops and symbiotic microbes on phosphatase gene and organic phosphorus hydrolysis in subtropical orchard soils. Soil Biol. Biochem. 2015, 82, 119-126. [CrossRef]

47. Bastida, F.; Torres, I.F.; Romero-Trigueros, C.; Baldrian, P.; Vetrovsky, T.; Bayona, J.M.; Alarcon, J.J.; Hernandez, T.; Garcia, C.; Nicolas, E. Combined effects of reduced irrigation and water quality on the soil microbial community of a citrus orchard under semi-arid conditions. Soil Biol. Biochem. 2017, 104, 226-237. [CrossRef]

48. Lauber, C.L.; Strickland, M.S.; Bradford, M.A.; Fierer, N. The influence of soil properties on the structure of bacterial and fungal communities across land-use types. Soil Biol. Biochem. 2008, 40, 2407-2415. [CrossRef]

49. Rousk, J.; Baath, E.; Brookes, P.C.; Lauber, C.L.; Lozupone, C.; Caporaso, J.G.; Knight, R.; Fierer, N. Soil bacterial and fungal communities across a pH gradient in an arable soil. ISME J. 2010, 4, 1340-1351. [CrossRef] [PubMed]

50. Lucas, R.W.; Klaminder, J.; Futter, M.N.; Bishop, K.H.; Egnell, G.; Laudon, H.; Högberg, P. A meta-analysis of the effects of nitrogen additions on base cations: Implications for plants, soils, and streams. For. Ecol. Manag. 2011, 262, 95-104. [CrossRef] 
51. Wessen, E.; Hallin, S.; Philippot, L. Differential responses of bacterial and archaeal groups at high taxonomical ranks to soil management. Soil Biol. Biochem. 2010, 42, 1759-1765. [CrossRef]

52. Ramirez, K.S.; Craine, J.M.; Fierer, N. Nitrogen fertilization inhibits soil microbial respiration regardless of the form of nitrogen applied. Soil Biol. Biochem. 2010, 42, 2336-2338. [CrossRef]

53. Cusack, D.F.; Silver, W.L.; Torn, M.S.; Burton, S.D.; Firestone, M.K. Changes in microbial community characteristics and soil organic matter with nitrogen additions in two tropical forests. Ecology 2011, 92, 621-632. [CrossRef]

54. Guan, X.Y.; Wang, J.F.; Zhao, H.; Wang, J.J.; Luo, X.M.; Liu, F.; Zhao, F.Q. Soil bacterial communities shaped by geochemical factors and land use in a less-explored area, Tibetan Plateau. BMC Genom. 2013, 14, 820. [CrossRef]

55. Shen, Z.; Wang, D.; Ruan, Y.; Xue, C.; Zhang, J.; Li, R.; Shen, Q. Deep 16S rRNA pyrosequencing reveals a bacterial community associated with Banana Fusarium Wilt disease suppression induced by bio-organic fertilizer application. PLoS ONE 2014, 9, e98420. [CrossRef] [PubMed]

56. Yin, C.; Hulbert, S.H.; Schroeder, K.L.; Olga, M.; Dmitri, M.; Amit, D.; Schillinger, W.F.; Paulitz, T.C. Role of Bacterial Communities in the Natural Suppression of Rhizoctonia solani Bare Patch Disease of Wheat (Triticum aestivum L.). Appl. Environ. Microbiol. 2013, 79, 7428-7438. [CrossRef] [PubMed]

57. Yarwood, S.A.; Myrold, D.D.; Gberg, M.N.H. Termination of belowground C allocation by trees alters soil fungal and bacterial communities in a boreal forest. FEMS Microbiol. Ecol. 2009, 70, 151-162. [CrossRef] [PubMed]

58. Chitapornpan, S.; Chiemchaisri, C.; Chiemchaisri, W.; Honda, R.; Yamamoto, K. Organic carbon recovery and photosynthetic bacteria population in an anaerobic membrane photo-bioreactor treating food processing wastewater. Bioresour. Technol. 2013, 141, 65-74. [CrossRef] [PubMed]

59. Zheng, X.; Chen, Y.; Wu, R. Long-term effects of titanium dioxide nanoparticles on nitrogen and phosphorus removal from wastewater and bacterial community shift in activated sludge. Environ. Sci. Technol. 2011, 45, 7284. [CrossRef]

60. Kargi, F.; Eker, S. Performance of rotating perforated tubes biofilm reactor in biological wastewater treatment. Enzym. Microb. Technol. 2003, 32, 464-471. [CrossRef]

61. Hashemi, S.; Han, M.; Kim, T. Optimization of fertilization characteristics of urine by addition of Nitrosomonas europaea bio-seed. J. Sci. Food Agric. 2016, 96, 4416-4422. [CrossRef] 